\title{
Coping Strategies of farm women during Corona pandemic in North Karnataka
}

\author{
Geeta P. Channal and Rekha Rayangoudar
}

Received: 09.10.2020; Revised: 08.11.2020; Accepted: 25.11 .2020

See end of the paper for authors' affiliations Geeta P. Channal

University of Agricultural

Sciences, Dharwad (Karnataka)

India

Email : geetrajpatil@yahoo.co.in
ABSTRACT : Indian population depends on agriculture for their livelihood and they face many problems like flood, drought but COVID-19 was new challenge to the farmers. It created many problems like non availability of labour, equipments, transport facilities, storage facilities, marketing and many more. The study was conducted in Dharwad district of Karnataka during 2020 for 60 farm women from two villages of Hubli taluk by simple random method. The results revealed that 55 per cent of the farm women were in the age group of 31-50 years with medium sized family. Around 88.00 per cent knew COVID-19/Corona is a viral disease and cent per cent of the respondents knew that cough and fever were the sympots of Carona and should stay at home and not to go for work also. Three fourth of the farm women (78.33) expressed that they used to consume hot water. Indigenous practices like turmeric in hot water and ginger tea are the regular practice of the people and regularly they wash all vegetables and fruits before consumption. Eighty per cent said they are aware of only few things to develop immunity against Covid-19. Efforts by different departments should be made to create awareness regarding farming families health and other problems.

KEY WORDS: Corona, Pandemic, Coping strategies, Farm women

- HOW TO CITE THIS PAPER : Channal, Geeta P. and Rayangoudar, Rekha (2020). Coping Strategies of farm women during Corona pandemic in North Karnataka. Asian J. Home Sci., 15 (2) : 357-360, DOI: 10.15740/HAS/AJHS/15.2/357-360. Copyright@2020: Hind Agri-Horticultural Society. 